\title{
Burocracia e Estado Capitalista: Notas sobre a Reforma (Administrativa) de Estado
}

\author{
Marcelo Simóes Pires Picarelli ${ }^{\mathrm{i}}$
}

I Introdução. 2 Administraçāo Pública e Govemo. 3 Burocracia e Estado Capitalista. 3.1 Do Estado Moderno à Reforma do Welfare State. 3.2 A Crise do Welfare State e a Proposta Neoliberal. 4 Análise Frankfurtiana da Reforma de Estado. 4.1 Estado e Economia sob a Perspectiva da Teoria Crítica. 4.2 Crítica da Reforma Neoliberal. 5 Conclusão. Referências.

Resumo: A partir da década de 1980, tornaram-se evidentes, nos países capitalistas ocidentais, diversos processos de reforma no mais característico modelo de Estado do pós-guerra: o Welfare state. Confrontadas com a emergência dos mercados globais, tais reformas apresentaram um novo paradigma, năo keynesiano, para a atuação econômica e social do Estado, a fím de enfrentarem a crise de (năo)governabilidade por que estavam passando, representados por déficit público, inflação e desemprego. Essas reformas, dițas neoliberais ou pró-mercado, contềm também um aspecto especificamente administrativo, que apresentou como alternativa ao modelo burocrático weberiano a Nova Administraçāo Fública (ou administração gerencial), que preconiza a adoção de princípios e instrumentos oriundos da iníciativa privada, com o intuito de tomar a atuaçāo estatal mais eficiente. O presente artigo pretende efetuar uma discussão teórica, em nivel de princípios da açâo estatal, a fim de elucidar os requisitos e conseqüências das alterações na forma de atuação do Estado contemporâneo, de feiçāo burocrática e de caráter social, levadas a cabo pelas reformas de Estado neoliberais. Para tanto, foi utilizada a matriz teónica da "Escola de Frankfurt", formuladora da Teoria Crítica, que apresenta uma abordagem marxista e freudiana, para analisar o papel da burocratizaçăo nas sociedades industrializadas ocidentais do pós-guerra. O ponto de partida é a análise da burocracia efetuada por Weber, e o desenvolvimento dos seus conceitos frente ao mundo contemporâneo, temas tratados por Marcuse e Habermas, dentre outros.

Palavras -chave: Burocracia. Escola de Frankfurt. Neoliberalismo. Reforma de Estado. Weber.

Abstract: Since the 1980's, that have been evident, in the occidental capitalistic couritries, plenty reform process in the most characteristic post-war model

\footnotetext{
"Mestre em Ciência Política pelo IFCH/UFRGS no ano de 2001, com a dissertação: "Reforma (Administrativa) de Estado neoliberal e pesquisa de opiniäo como instrumento de avaliaçao dos serviços públicos: uma análise frankfurtiana". Graduado em Direito UFRGS, no ano de 1997. Delegado de Foĺcia Federal, lotado na Delegacía de Policia Federal em Santa Cruz do SulRS.
} 
State: the Welfare State. Confronted with the global markets emergency, such reforms presented a new paradigm, not Keynesian, for economic and social performances of the state, to aim of confront the (not) governability crisis through what were passing by, represented by public deficit, inflation and unemployment. Such reforms, called neoliberals or pro-market, contain too a specific management aspect, that presents as option of the weberian bureaucratic model the New Public Management, witch proclaims adopting principles and instruments derived from private initiative, with the aim to become the state performance more efficiency. The present article aimed to do a theoretical discussion, on the level of principles of state performance, with the aim of make clear the requisites and consequences of the change on the contemporary state way of performance, from bureaucratic form and social character, realized by neoliberal state reforms. To that, was utilized theoretical matrix of "Frankfurt School", formulator of the Critical Theory, which presents a Marxist and Freudian approach, to analyze the role of the bureaucratic form in the industrialized occidental of post-war societies. The start point is the bureaucracy analysis realized by Weber, and the development of its concepts faced to the contemporary world, themes treated by Marcuse and Habermas, among others.

Keywords: Bureaucracy. Frankfurt School. Neoliberalism. State Reform. Weber.

\section{Introdução}

No final dos anos 1970, quando o mundo viveu a segunda crise do petróleo e a enorme inflação americana, o Federal Reserve (Banco Central dos EUA) elevou a taxa de juro

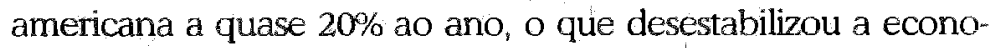
mia global pelas décadas seguintes. Atribuiu-se aquela crise mundial a um excesso de regulação dos mercados por parte dos Estados, portanto, tal regulação passou a ser dissolvida paulatinamente pela visão hegemônica liberal, com a ilusão de que o mercado se auto-regularia e buscaria sempre pontos de equilítorio para seu perfeito funcionamento. A funçẩo dos Estados deveria ser auxiliar os mercados a atingir tais pontos. O recente baque econômico da "bolha imobiliária" norte-americana de 2008 trouxe como conseqüência novamente grande intervenção dos Estados ocidentais nos mercados financeiros, visando a impedir o aprofundamento de uma crise sistêmica. Esta recente atuaçăo dos Estados ocidentais 
capitalistas tem sido apontada como o epitáfio da era Reagan e Tatcher, e sua visão "neoliberal".

Tal visão dominou os governos dos países com as principais economias mundiais durante os anos 1980 e a década seguinte, período em que a referida crise econômica trouxe como consequêencia o questionamento do modelo de desenvolvimento para os países ocidentais, afetando o rumo da política econômica em muitos Estados, permitindo a ascensão da visão liberalizante dos mercados. Na Europa, houve o rompimento do consenso keynesiano das décadas do pósguerra, e, na América Latina, ocorreu o abandono do protecionismo da substituição de importações (SCHIRM, 1999). Com efeito, o tema de reforma do modelo de Fstado dominou a agenda política internacional dos anos 1990 , e é apontado como um desafio necessário, devido à crise de governabilidade por que estariam passando os Estados ocidentais, em seus aspectos econômico, social e, este último nos é relevante, administrativo.

O tamanho e o modo de intervenção do Estado na sociedade e na economia passou a sofrer reformulaçöes significativas, como países da Organização para Cooperação e o Desenvolvimento Econômico (OCDE), sobretudo Reino Unido, Nova Zelândia, Austrália $€$ os países escandinavos, organizaram processos de reforma de suas máquinas administrativas, imprimindo-lhes um caráter mais gerencial, inspirado nas experiências da administração privada. As correlatas reformas administrativas patrocinadas pelos organismos intemacionais (em especial o Banco Internacional para Reconstruçâo e Desenvolvimento - BIRD) estruturaram-se tendo por base teónica a Nova Administração Pública, mais conhecida como Administraçäo Gerencial (ou Empreendedora), segundo Pereira (1997). Um de seus principais pressupostos é a administração voltada para o cidadâo, que se define como modelo gerencial, cujo objetivo é oferecer serviços públicos de maior qualidade, atendendo melhor as demandas dos usuários de serviços públicos (COUTINHO, 2000, p.47). 
Segundo Andrews e Kouzmin (1998), a Nova Administração Pública orienta-se pela Teoria da Escolha Pública, que foi desenyolvida por economistas neoclássicos da "Escola de Virgínia". O seu pressuposto é o racionalismo econômico, segundo o qual os indivíduos são maximizadores econômicos, motivados só pelo auto-interesse nas interaçôes econômicas, políticas e sociais. Seus elementos são: o pressuposto do auto-interesse, a concepção de interações sociais como trocas no mercado e o individualismo metodológico.

A Escolha Pública pretende cumprir a tarefa de reconstrução do Estado, com o objetivo de ajudar as indústrias a competir nos mercados internacionais e a proteger os cidadãos das desigualdades dentro e entre os países, por meio das seguintes ações, conforme Coutinho (op. cit.):

a) Diminuição do tamanho do Estado: privatização, terceirização e publicização (passagem dos serviços públicos para organizaçóes não-governamentais);

b) Desregulação da economia: adoção de mecanismos de mercado para regulação econômica;

c) Aumento da governança, entendida como capacidade do Estado tomar decisöes efetivas: ajuste fiscal, administração gerencial, separação entre os órgãos que formulam e os que implementam as políticas públicas;

d) Aumento da governabilidade, entendida como capacidade política do Governo de intermediar interesses: via melhoria da democracia representativa e via introduçẩo do controle social do Estado.

Tal orientação de Reforma de Estado, baseada na perspectiva empresarial, foi considerada justificável, devido ao sucesso que algumas empresas de ponta obtiveram implantando programas que valorizavam as necessidades dos seus clientes, em virtude do ambiente marcadamente competifivo em que passaram a operar com a (abertura dos mercados nacionais proporcionada pela) globalizaçăo e com as mudanças tecnológicas ocorridas nas últimas décadas, devido à 
revolução eletro-eletrônica. Decorrentemente, o racionalismo econômico apresentou-se como verdadeira base ideológica da globalizaçấo e das necessárias reformas de Estado (Andrews, Kouzmin, op. cit).

É relevante pontuar aqui que a discussão contemporânea acerca da reforma do Estado, especialmente em relação ao seu aspecto administrativo, impōe para a compreensão de sua abrangência a busca de formulações teóricas que abarquem o Estado, em suas relaçōes com a sociedade, o mercado e a política (Diniz, 1998). Esse tema é tão controverso quanto abrangente (uma vez que abarca áreas da Ciência Política, do Direito, da Economia da Administração e da Filosofia Política, além de outros ramos do conhecimento humano) e com grandes implicações quanto à forma e ao conteúdo da atuação do próprio Estado.

No presente artigo, será efetuada uma abordagem teórica acerca da administração estatal (com seu modo burocrático de atuação) e sua relação com o Estado capitalista contemporâneo, a fim de subsidiar programas de reforma que se pretendam auxiliares dos processos de gestấo, e capazes de melhorar a eficiência da atuaçăo do Estado, no contexto brasileiro. $O$ objetivo geral do trabalho será demonstrar que qualquer proposta de reforma de Estado que tenha por fim aumentar a governabilidade (e a governança) do Estado, por meio de uma maior eficiência na sua atuaçăo e na prestação dos serviços públicos, com reflexo na melhoria das condiçôes de vida da população, năo pode passar apenas pela dimensão técnica da forma de atuação do Estado, e simplesmente reproduzir as experiências do setor privado. Deve, antes de tudo, também superar questōes epistemológicas e enfrentar uma reformulação dos princípios da ação estatal.

\section{Administração Pública e Governo}

Iniciarei traçando definiçốes de alguns conceitos que instrumentalizarão a reflexão posterior. Para se apreender 
o funcionamento das instituiçōes, do título anteriormente posto, na sociedade ocidental capitalista contemporânea, começarei trabalhando o conceito de associação. Por este, compreende-se uma relação entre um conjunto de indivíduos, com uma regulação limitadora, enquanto a manutenção de sua ordem está garantida pela conduta de determinadas pessoas. Segundo Weber (1922), a administração de uma associação depende por completo da presença de um dirigente $e_{\text {, }}$ eventualmente, de um quadro administrativo que a organize. Dessa forma, considera que há uma associação quando a manutenção de sua ordem está garantida pela conduta de determinadas pessoas, destinada, em especial, para tal propósito: um dirigente e, eventualmente, um quadro administrativo que, conforme o caso, pode também apresentar-se com um poder representativo.

Nesse sentido, a associação não consiste em outra coisa que em "la existencia de la probabilidad de que pueda tener lugar una acción de personas dadas, cuyo sentido esté en el propósito de implantar el onden de la asociación" (Weber, 1922 1997:39). Ou seja, na possibilidade de uma ação conjunta com um fim, um propósito, em comum, qual seja, implantação de uma ordem. Se este tipo de ação orientada a um fim não está presente, configura-se uma relação social, mas não uma associaçẫo.

A ação da associação, portanto, é efetuada pelo seu quadro administrativo ou dirigida e planejada por este, $e$ orientada a implantar, modificar ou manter uma determinada ordem. À medida que a associação vaí crescendo há uma tendência a sua oligarquizaçāo, efetuada por meio de uma organização burocrática. Robert Michels (1911), estudando os problemas decorrentes da organizaçâo dos partidos políticos operários, percebeu que toda organização, à medida que cresce, tende a se burocratizar; é a denominada "lei de ferro da oligarquização". Dentro do Estado, não parece haver diferença. A burocratização, pois, apresenta-se numa temática inerente às questốes relativas à administração do Estado, e no que consiste esta. 
Chiavenato $(1987$, p.3) coloca que a palavra administração tem suas onigens no latim ( $a d$, direção para, tendência; minister, comparativo de inferioridade; e sufixo ter, subordinação ou obediência, isto é, "aquele que realiza a função abaixo do comando de outrem, aquele que presta um serviço ao outro"). Logo, em sua origem, a palavra administração significa função que se desenvolve sob o comando de outro, um serviço que se presta a outro. $O$ voćábulo administração, em linhas gerais, abrange tanto a atividade superior de planejar, dirigir, comandar, como a atividade subordinada de executar.

Conforme a teoria jurídica romano-germânica² do Direito Administrativo (Di Pietro, 1999, p.48), pode-se apontar que, seja nas relações entre particulares (ditas privadas) ou nas entre o Estado e um particular (ditas públicas), ${ }^{3}$ os atos de administração limitam-se aos de guarda, conservação e percepção dos frutos dos bens administrados; portanto, não incluem os de alienação. Neles, há sempre uma vontade externa ao administrador a impor-lhe a orientação a seguir. Assim, na administração, o dever e a finalidade são predominantes; já no domínio, é a vontade. A adiministração, então, é a atividade daquele que não é senhor absoluto. Tanto na administraçấo privada como na pública há uma atividade dependente de uma vontade externa, individual ou coletiva, vinculada ao princípio da finalidade. Portanto, não é errôneo, inclusive, afirmar que toda atividade de administração deve

\footnotetext{
${ }^{2}$ A familia Romano-Germânica abrange países nos quais a Ciência do Direito se formou sobre a base do direito romano (oeste do continente europeuj), concebendo as regras de direito como sendo regras de conduta, ligadas a preocupaçōes de justiça e de moral. Caracteriza-se pelo estabelecimento de estatutos legais, formando um sistema, com regras gerais que devem ser aplicadas a cada caso concreto levado à justiça. A família da Common Law, característica dos países anglo-saxões, desenvolveu-se na Inglaterra e sua preocupaçăo é dar solução a um processo em concreto. e nâo formular uma regra geral de conduta para o futuro. Sua preocupação Imediata é o restabelecimento da ordem perturbada, e não a de lançar as bases da sociedade. É um Direito nẫo escrito, baseado no costume, no uso e nas decisóes das cortes de justiça. (David, 1993)

${ }^{3} \mathrm{Na}$ Common Law, a Administração age como se fosse um particular, seguindo o regime jurídico de Direito privado.
} 
ser útil àquele interesse que o administrador deve satisfazer. No caso da Administraçáo Pública, a vontade decorre da lei que fixa a finalidade que deve ser perseguida pelo administrador, ou deveria.

Concebe-se que, em sentido subjetivo (MEIRELLES, 2000), a Administração Pública compreende tanto os órgãos governamentais supremos e constitucionais (Governo), aos quais incumbe traçar os planos de ação, dirigir, comandar; quanto os óngáos administrativos subordinados e dependentes (Administração Pública [stricto sensu]), aos quais incumbe executar os planos governamentais.

Infere-se, por conseqüência, que, na teoria jurídica nacional, a Administração Pública compreende 1) a função política, que traça as diretrizes govemamentais e 2) a função administrativa, que as executa. Existe uma preponderância do Poder Executivo no exercício das atribuiçóes políticas; mas näo existe exclusividade no exercício dessa. Pode-se dizer que na organização administrativa do Estado brasileiro, por exemplo, as funções políticas repartem-se entre Executivo e Legislativo, com acentuada predominâncía do primeiro.

Feitas estas observaçóes, será tomado por base o conceito de Administração Pública em sentido estrito, que engloba, num sentido subjetivo: as pessoas jurídicas, os órgãos e os agentes públicos que exercem a função administrativa; e, num sentido objetivo: a atividade administrativa exercida por aqueles entes. Toda esta atividade da função administrativa dá-se basicamente pela Burocracia do Estado, que será examinada a seguir.

\section{Burocracia e Estado Capitalista}

A burocracia apresentou-se, no século XX, como um dos mais relevantes temas dentro da Sociologia e da Ciência Política, possuindo como pano de fundo relaçöes de poder e de controle. Esta problemática surgiu como preocupaçäo intelectual no ocidente apenas no séc. XVIH, embora o fenômeno 
seja muito mais antigo ${ }^{4} \mathrm{Um}$ economista fisiocrático da época, Vicent de Gournay, utilizou o termo "burocrático" para designar o poder do corpo de funcionários e empregados da administração estatal, incumbidos de funções especializadas na monarquia absoluta, dependentes do soberano. $\mathrm{O}$ poder está aqui sendo utilizado como competência específica ligada a determinada tarefa.

No séc. XIX, o mesmo tema também assumiu conotação política, na medida em que passou a ser usado por liberais e radicais para criticar o formalismo, a altivez e o espírito da administração pública nos regimes autoritários, especialmente na Alemanha prussiana de Bismarck (1815-1898), o "Chanceler de Ferro". O uso crítico do termo que se institucionalizou na linguagem comum atual costuma indicar a proliferação de normas e regulamentos, o ritualismo, a falta de iniciativa, o desperdício de recursos, a burocratização, ou seja, a ineficiência das grandes organizações públicas e privadas. Aqui deve ser reafirmado que, conceitualmente, burocracia não se equivale à burocratização. Uma vez considerada como principal característica da burocracia (em seu tipo-ideal), a racionalidade de seu proceder, com decorrente centralização da autoridade e a impessoalidade dos comandos em busca de uma maior eficiência na atuação de uma associação; por burocratização, pode ser entendido o advento de elementos de não-racionalidade, de fragmentação de autoridade e de personalismo (patrimonialismo) ou de despersonalizaçấo dos comandos.

Burocratizaçăo significa proliferaçâo de organismos sem conexão com as exigências gerais da funcionalidade; acentuação dos aspectos formais e processuais sobre os aspectos substanciais com a consequente morosidade das atividades e redução das tarefas desempenhadas,

\footnotetext{
4 No antigo Egito, na Mesopotâmia e na China formouse um Estado de caráter centralizado e despótico que realizava seu domínio, via domínio das águas, submetendo os cultivadores à direção de uma classe letrada de funcionários que planejavam e executavam o plano. (Tragtenberg. 1992, p.27)
} 
sobrevivência e elefantíase de organismos que não desempenham mais alguma função efetiva $e$, finalmente, triunfo da organização - a burocracia - sobre suas funcionalidades. (Bencini. In: Bobbio et al., op. cit., p.130)

Para trabalhar o termo no presente artigo, partirei de uma das primeiras definiçōes, que se delineou no século XIX, segundo Girglioli (apud Bobbio et al, 1997), e que expres. sava uma concepção de Burocracia, procurando empregar o termo em um sentido técnico e não polêmico: trata-se daquele conjunto de estudos jurídicos e da ciência da administração alemães que versam sobre "Bureausystem". Este era o novo aparelho administrativo prussiano, organizado monocrática e hierarquicamente (a partir dos bureaus), em substituição aos velhos corpos administrativos colegiais (de característica estamental). Por esta tradição técnico-jurídica, o conceito de Burocracia designa uma teoria e uma praxe da adminiștração pública que é considerada a mais eficiente possivel, e tem sua legitimidade justamente baseada na eficiência com que trata a administração do Estado.

Portanto, a organização burocrática é uma específica variante moderna (com raízes iluministas) das soluçōes dadas ao problema geral da administração (tanto pública como privada). A burocracia é o tipo ideal de uma estrutura pura de dominação através de um quadro administrativo, isto é, da Dominação Racional-Legal. As categorias fundamentais para se apreender a atuação do quadro administrativo na dominação legal, segundo Weber (1997) são: a) o exercício (sujeito a lei) continudado de funçóes; dentro da sua b) competência, com atribuição dos poderes necessários para sua realizaçấo e com fixação estrita dos meios coativos eventualmente admissíveis e os pressupostos de sua aplicação. Acrescentado do c) Princípio da Hierarquia Administrativa: ordenação de "autoridades" fixas com faculdades de regu-lação e inspeção e com o direito de queixa ou apelação ante instâncias superiores, por parte das inferiores.

O integrante do quadro nâo é o proprietário da máquina administrativa, só possui o sabẹer técnico, o que já é um 
elemento de reforço à hierarquia. Assim, o grande instrumento da superioridade da administração burocrática é o saber profissional especializado, cujo caráter imprescindível está condicionado pelos caracteres da técnica e da economia moderna da produção de bens, em última instância, está condicionada pela ciência (racionalidade formal).

Para Weber, a industrialização e o capitalismo constituem as realizações decisivas dessa racionalidade ocidental, e essa, por sua vez, é responsável por distingui-los de modo fundamental de todas as outras formas de técnica e de economia que já existiram. Por tal análise, a racionalidade instrumental, encontra-se também institucionalizada na vida cotidiana da sociedade, traduzindo-se, no plano econômico, na ação calculada dos agentes econômicos (empresários) e na atuação competente da administração estatal (burocratas). Weber demonstrou que a razăo econômica nẩo se confinou à área da produção e circulação de mercadorias, mostrou que a calculabilidade e previsibilidade, características essenciais da racionalidade instrumental na economia, permearam também a esfera política, impondo-se inclusive como "razão de Estado".

Contudo, essa racionalidade para a organização da atividade da burocracia apresenta uma inerente disfunção estrutural, uma vez que a administração burocrática é aquela forma de organização social que, devido à sua constituição, não pode tematizar suas próprias premissas. Há uma rígida divisão entre aqueles que decidem e aqueles que executam as açöes. Assim, a sua racionalidade, como imposiçäo das normas estabelecidas e execução sem distorções por questóes subjetivas ou pessoais, só se estabelece com a disjunção total entre as premissas da ação e o aparelho que as executa, com vistas a maior eficiência possível quanto ao agir (Offe, 1984). Eficiência, aqui, é vista como rígido cumprimento das normas estabelecidas, ou seja, subordinaçäo confiável de açōes a premissas.

Desse modo, uma vez preenchidos os requisitos formais, aquele que deve cumprir as ordens não tem o dever 
nem a capacidade de questioná-las. Por conseqüência, apesar da certeza de que os mandamentos serão cumpridos, ocorre, para a organização, uma perda de capacidade de reflexão sobre a própria atividade que se está realizando, perde-se de vista o próprio fím almejado pela ação. Tornase a regra da atuaçăo burocrática o formalismo, ou seja, o culto à forma (quase sempre escrita) exigida para o agir e seus requisitos, acarretando uma perda de noção entre os fins e os meios.

Desde a afirmação da Burocracia como modo mais eficiente de administrar o Estado, emergiu a relativa problemática a partir da constatação de que ela é, ao mesmo tempo, um processo indesejável e irremediável. Indesejável, na medida em que se opōe à democracia plena, conduzindo as sociedades a uma democratização passiva, ou a um nivelamento entre dominantes e dominados. Irremediável, porque está associada ao fenômeno da democracia de massas, sendo uma forma possível de administrá-la em opo-sição à autonomia administrativa e democrática de pequenas unidades homogêneas, improvável em uma grande sociedade industrial (TRAGTENBERG, op. cit.).

Para se apreender de forma mais precisa, o que implica o fenômeno burocrático na atualidade, trabalhar-se-á com as transformaçōes ocorridas a partir do Estado moderno, e com as origens e as relações da burocracia com o sistema de mercado e a produção capitalista.

\subsection{Do Estado Moderno à reforma do Welfare state}

A centralização política necessária para a formação do Estado Nacional Moderno - Estado unitário dotado de um poder próprio independente - tendeu ao absolutismo monárquico (GRUPPI, 1980), daí a íntima correlação que se fez do conceito de burocracia com centralização e autoritarismo. Com o desenvolvimento do capitalismo, nos séculos XVII e XVIII, a burguesia continuou sua ascensão econômica nos países europeus ocidentais. Os burgueses, conscientes de seus interesses, passaram a criticar o Antigo Regime. 
Contestações liberais atuaram no confronto deste Estado absolutista, tendo por resultado uma forma de organização que se pode denominar Estado Liberal. Seus principais marcos instituidores no ocidente foram as revoluçōes Gloriosa (1688-1689), ${ }^{5}$ a de Independência dos Estados Unidos da América (1781) e a Francesa (1789).

Seu fundamento teórico inspirador foi o lluminismo, que, no caso francếs, remete à Enciclopédia, à Era da Razão. O Iluminismo é um movimento de idéias cujas origens remontam até o séc. $X V_{1}$ e que vieram a se desenvolver especialmente no séc. XVIII. Esse movimento visava a estimular a luta da Razão contra a Autoridade, isto é, a luta da "luz" contra as "trevas". Constituía-se, pois, em uma filosofia militante de crítica da tradição cultural e institucional, cujo programa consistia na "difusão do uso da razão para dirigir o progresso da vida em todos os aspectos" (Binetti, apud Bobbio et al., 1997:605). Os iluministas conceberam a idéia de Progresso como um contínuo e indefinível melhoramento institucional, econômico, moral e civil, abandonando a imagem (medicval) da história como uma decadência contínua e gradual. Tal melhoramento tenderia a ser tanto mais forte quanto mais a razão assumisse o papel de guia desse processo.

Por conseguinte, a Época das Luzes havia inspirado toda a Europa com uma irrestrita confiança no poder da ciência e da lógica para resolver, finalmente, todos os problemas (e emancipar os homens da condiçấo da miséria) ilustrando a "infinita perfectibilidade" do ser humano. Para tanto, não existiria outra chave para se chegar à Utopia de Bacon ${ }^{6}$ que nāo a organização racional para todas as questões que envolviam a sociedade. (DURANT, 1996)

\footnotetext{
As tropas comandadas por Oliver Cronwel foram formadas segundo um New Model Army, isto é, os postos de comando desse exército eram conquistados pelo critério de merecimento militar e nầo pela origem de familia. A adoçáo deste critério estimulou os combatentes, contribuindo para o fortalecimento da revolta liberal.

${ }^{-}$Em Nova Atlântida, Ftancis Bacon professa uma sociedade na qual a ciencia está a servico do aperfeiçcamento da ordem social e da organização da vida das pessoas, com o objetivo de alargar as fronteiras do império humano para executar tudo o gue for possivel.
} 
A esfera econômica tendia ao liberalismo, tendo a economia sido considerada como um dos principais instrumentos de racionalizaçâo da vida, e passado a ser vista como um meio na mão dos soberanos. A doutrina econômica tipicamente iluminista foi a Fisiocracia, que fundamentava a idéia da existência de uma ordem natural regida por leis eternas, às quais seria mais racional conformar-se, pois elas tenderiam a produzir a máxima prosperidade e harmonia possíveis, uma vez năo obstadas. A legislação positiva editada pelo Estado, portanto, deveria favorecer a explicação da ordem natural, concedendo a máxima liberdade econồmica,

O liberalismo também se caracterizou por ser uma concepção individualista, com os valores individuais sendo superiores aos coletivos. Uma concepção para a qual o indivíduo, e não os grupos, constituía a verdadeira essência da sociedade, e seria ele quem decidiria seu destino e faria a história. Sua orientação era a filosofía da libertação, porém, de um ideal realizado intelectualmente, năo socialmente. A liberdade de comércio, a abolição de privilégios e imunidades (de origens feudais, concedidas em função de títulos nobiliários aos condes, marqueses etc.), a divulgação da cultura e a revisão do sistema fiscal eram as aspiraçōes dos iluministas, e, mais especialmente, as aspiraçôes da burguesia. Pode-se afirmar que o lluminismo era a filosofia do terceiro Estado (no caso francếs), mas nẩo a do povo, em relação aos quais os philosophes nutriam certa desconfiança, enquanto não fosse realizada sua educação.

Juridicamente, os direitos individuais foram o principal baluarte (formal) deste período e apresentaram como fundamento, por um lado, a destruição das bases que sustentavam o complexo dos direitos medievais, e, por outro, o nascimento de novos conceitos de natureza ideal e social. A política absolutista, com sua tendência de poder sem limites e pela conseguinte abolição dos poderes intermediários (se. nhores feudais), colocou frente a frente o Estado e o indivíduo. A teoria jurídica dos direitos individuais foi a barreira de limite criada para a atuação do Estado. 
Além das garantias dos direitos individuais (e superior a estas), o Estado liberal cuidou de assegurar um sistema geral de garantias do sistema, que se tornou possível graças à estruturação da Teoria da Constituição? (código jurídico-político com referência a um esquema racionalmente criado). Pode-se considerar uma estrutura como racional quando possui uma ordenaçăo de órgãos e atos estabelecida de tal maneira que conduza a um objetivo previamente fixado, recebendo todas as partes da estrutura um papel funcional com respeito à finalidade prevista. A teoria constitucional resultou na divisão clássica dos poderes (Legislativo, Executivo e Judiciário) e no Estado de Direito.

Portanto, o Estado liberal não nasce no absolutismo, mas carregará consigo as conseqüências de um processo que nesse teve origem: havia começado o processo de racionalização da organização estatal, que se manifestou antes de tudo na ordenação burocrática da administração. Porém, foi deixado espaço de onde remanesceram partes irracionais no sistema, pois o processo racional não havia chegado ao cume do Estado, já que o rei o era "pela graça de Deus".

Quanto à questão específica da administraçầo do Estado, pode-se dizer que a centralização administrativa no Estado Moderno foi patrocinada por setores da nobreza e da burguesia interessados no fortalecimento da autoridade do rei, pois assim o Estado se tomaria um instrumento mais eficaz para reprimir as revoltas camponesas contra a nobreza feudal, proteger a propriedade das terras e os privilégios da nobreza; bem como para melhorar as estradas e a segurança pública, uniformizar as moedas e padronizar pesos e medidas, criar leis e procedimentos jurídicos de âmbito nacional - tudo com vistas ao desenvolvimento do comércio. Assim, para estes grupos sociais, o Estado com poder centralizado representava

\footnotetext{
${ }^{7}$ Por Constituição, pode-se entender um conjunto de regras ol princípios (escritos ou não) que têm por objeto a estruturação do Estado, a organização de seus órgãos superiores e a definiçâo de suas competências, ou seja, säo as nomas estruturajis de uma dada sociedade política. (Bastos, 1994)
} 
um caminho para a construção de sociedades mais prósperas e seguras. Dentre os meios de controle político da monarquia, podemos citar, ao lado da burocracia administrativa, a força militar permanente, a unificação das leis e da justiça e o sistema tributário. Essa unificação tornou mais racionais as relações sociais, favorecendo a Revo-lução Comercial, que propiciou o acúmulo de riquezas neces-sário para a expansâo marítima.

Já no Estado liberal burguês, resultante das revoluçốes do séc. XVIII, a administração também intervinha na socie dade, porém de forma mitigada em relação ao Estado absolutista, sempre que ela intervinha na esfera da propriedade e da liberdade o fazia vinculada a normas legais gerais (iguais em toda a circunscrição do Estado), que deveriam reproduzir aquelas encontradas na natureza das coisas.

O Estado também passou a atuar sob o império da lei, apresentando por características a separação entre a justiça e a administração, a crescente divisão do trabalho, assim como regras (gerais) para as atividades administrativas. Estas terminaram por conferir à administração liberal uma medida maior de previsibilidade e racionalismo em relaçăo à medieval, facilitando os fluxos de comércio, favorecendo a Revolução Industrial. Contudo, no liberalismo, a administração não perde o elemento de força e poder autoritário que possuía no absolutismo: o Estado liberal reprime os movimentos revolucionários sociais de forma igualmente impiedosa, e assegura, da mesma forma, a disciplina laboral nas empresas privadas mediante intervenção da força pública. Garante, com seus meios coativos, a estrutura e a eficácia dos mecanismos que produzem a subordinação social. Os escritores liberais clássicos acreditavam que a liberdade e a independência eram as realizaçổes mais valiosas da sociedade, e que mereciam ser protegidas, em todas as circunstâncias, contra as ameaças igualitárias da sociedade de massa gerada pela industrialização, uma vez que esta tenderia a levar à tirania (através da "legislação de classe") de uma maioria destituída de propriedade e de educação. (OFFE, 1983) 
O Estado liberal, estruturado nesta versão clássica, apresentou-se em crise (final do séc. XIX e início séc. XX) pelo acirramento dessas contradiçōes em sua estrutura, decorrentes, dentre outros fatores, do acelerado desenvolvimento industrial e de suas conseqüencias sociais no período. Com a progressiva industrialização, pela passagem de um capitalismo competitivo para um capitalismo (nacionalmente) organizado, multiplicam-se as tarefas e a extensão da administração pública para dar conta de um insustentável estado de tensão nas cidades, por um desordenado processo de urbanização, de concentração de rendas, e pela questäo do proletariado. No plano extemo, o crescimento da produçáo industrial exigia cada vez mais a ampliação dos mercados consumidores, o que provocou uma ascendente concorrência econômica entre os grandes países industrializados, desembocando na Primeira Guerra Mundial (1914-1918).

A partir de então, a administração pública começa a intervir em quase a totalidade das esferas da sociedade e, sobretudo, no processo econômico. Através da nacionalização da educação, das estradas de ferro, dos serviços de correlos e de comunicações, a administração passa progressivamente a gerir funçôes que anteriormente se encontravam nas mãos da iniciativa privada. Estabelece serviços públicos que são necessários para o funcionamento da sociedade industrial, mas que não podem ser prestados pelas sociedades privadas baseadas apenas na lógica da rentabilidade, devido à necessidade de planejamento e coordenação que exigem neste novo cenário.

Como consequência ou resposta da crise do Estado liberal, houve, paralelamente, uma tendência no período dos Estados industriais se democratizarem no aspecto político, produzida pela introdução do sufrágio universal e igual, ao mesmo passo em que se formou um corpo de funcionários públicos cada vez maior, cuja competência ultrapassava em muito os limites da administração do Estado liberal, e cuja independência pessoal frente ao governo democrático (do 
qual há de ser simples órgão executivo) nunca havia sido tão ampla. Este processo perdurou com o fim da $2^{\mathrm{a}}$ Guerra Mundial (1939 1945), tomando-se hegemônica até recentemente a concepçăo da necessária participação dos Estados na condução da economia. A construção de um Estado com separação (clássica) de poderes converteu-se em uma concentração de poderes nas mãos da burocracia, e o Estado judicial e legislativo foi substituído pelo Estado administrativo burocrático Concomitantemente, porém, desapareceu quase por completo a contrapartida económica da administração no formato do Estado liberal, ou seja, a sociedade de produtores livres, independentes e competidores: houve sua substituição por grandes uniões comerciais (cartéis, trustes e monopólios).

Portanto, os governos dos Estados foram irremediavelmente obrigados a atuar no plano interno da sociedade, a fim de manter a integridade do sistema (econômico e) social em seus países, uma vez que o sistema formal (jurídico), simplesmente com suas garantias (separação dos poderes e liberdades individuais), por sí só, nẫo cumpria sua função de manutenção da unidade e ordem social. Inicialmente na Inglaterra, e, depois pelo resto da Europa e do mundo, constatou-se a necessidade da existência de uma assistência social como condição para a reprodução da mão-de-obra, necessária para que o processo industrial perdurasse no tempo como sistema. Tal constatação é o conceito básico da política do Estado de Bern-Estar Social (Welfare state), de forma que este se caracteriza como garantidor de tipos mínimos de renda, alimentaçâo, saúde, habitaçăo, educaçâo, assegurados a todo cidadâo, não como caridade, mas como direito político (Regonini, apud Bobbio et al, op. cit.).

Esse conceito estruturou a idéia de serviço público, variável no tempo e nas sociedades, mas que se exprime em geral nas atividades de interesse coletivo, cuja presença do Estado é imperiosa, que segue um procedimento de direito público. o Welfare state é a forma de Estado prestadora de serviços 
públicos por excelência. Meirelles (op. cit., p.306) define serviço público como todo aquele prestado pela Administração ou por seus delegados, sob normas e controles estatais, para satisfazer necessidades essenciais ou secundários da coletividade ou simples conveniência do Estado.

\subsection{A crise do Welfare state e a proposta neoliberal}

Desde o fim da Segunda Grande Guerra, todos os grandes Estados industrializados tomaram medidas que estendiam a rede dos serviços sociais, instituíam uma carga fiscal fortemente progressiva e intervinham na sustentaçăo do emprego ou da renda dos desempregados, aplicando uma política econômica keynesiana. Essa representava uma maior participação do Eștado no mercado interno, usando seus recursos, de maneira anticíclica como propulsores da produção: os gastos governamentais assumiam o mesmo papel dos investimentos privados, garantiam níveis mínimos de renda, em busca de um estado de pleno emprego.

O aumento destas intervençôes trouxe como conseqüências: o aumento da cota do Produto Nacional Bruto destinada à despesa pública; a transformação das estruturas administrativas voltadas para os serviços sociais em formas mais vastas e complexas; o crescimento em número e importância política da classe ocupacional dos "profissionais do

\footnotetext{
${ }^{8}$ John Maynard Keynes (1883-1946) observou que o curso normal do mercado parecia evidenciar uma sucessão de expansôes e contraçóes, como se fossem ondas sucessivas, comparáveis a um "respirar económico". E para tails flutuaçōes, ditadas pela relação entre poúpança e investimento, não haveria qualquer meca. nismo de seguranca. Aqui entraria o papel dos gastos govemamentais: quando a economia estivesse em contração, os gastos públicos destinar-se-iam a gerar emprego, renda e poupança, necessários para realimentar o ciclo económico e voltar a expansão. (Heilbroner, 1996)

- Tal aumento fol destinado sobretudo para formas de distribuição de renda. Numa economia de mercado (pura), a distribuiçắo do Produto Nacional pelos diferentes habitantes de um país está condicionada tanto à disponibilidade relativa dos fatores de produção como aos seus niveis de produtividade. Isso significa que, à medida que critérios puramente economicos de eficiencia são considetados como unico critério distributivo, a distribuição de renda gerada pelos habitantes do país
} 
Welfare" io (professores, médicos, assistentes sociais etc.). Assim, o Estado liberal deu lugar a um Estado ao mesmo tempo social, porque assumiu o papel de garantidor dos direitos sociais e do pleno emprego; e burocrático, porque o faz através de burocratas. Contudo, o Welfare state keynesiano passou a apresentar sinais de desgaste, passando por uma crise de governabilidade, que se refletiu juntamente com a crise econômica dos anos 1980, conforme pontuado na introdução deste artigo,

O atual momento do sistema econômico mundial acentuou e reacendeu o debate acerca da crise da (nẫo) governabilidade dos estados nacionais capitalistas, surgida já no final da década de 1960 (OFFE, 1979), reatualizando as questões relativas aos limites do crescimento econômico, e sua relação com o Estado (de bem estar) social. Pasquino (apud Bobbio et al., 1997) pontua que, apesar da pouca sistematicidade dos estudos referentes ao tema, coexistem três tendências de hipótese para a tesé da crise de govemabilidade, às quais os autores, em geral, aderem (inclusive combinando-as):

a) A não-govemabilidade se constituiria em um produto da sobrecarga de problemas aos quais o Estado procurou responder com a expansão de seus serviços e da sua intervenção, até o momento em que, inevitavelmente, surgiu uma crise fiscal. Por esta hipótese (O'CONNOR, 1973, apud Pasquino et al., 1997), associa-se a nāo-governabilidade à crise fiscal do Estado.

b) A não-governabilidade constituir-se-ía num problema de acumulação, distribuição e redistribuição de recursos, bens e serviços aos cidadãos de um determinado Estado; porém,

pode năo ser considerada socialmente aceitável, sobretudo no que diz respeito a grupos de individuos gue não integrem a população economicamente ativa (devido à idade; por exemplo). Estes grupos tenam rendimento nulo se cricérios puramente económicos fossem utilizados, o que justificaria as atividades relacionadas ao pagamento de pensoses e auxilios a aposentados ou à infância. (Rezende, 1983) io Estes aperfeiçoaram as técnicas da descoberta e avaliaçăo das necessidades sociais; assim, tomou-se mais claro o conhecimento do impacto das várias formas de assistência na redistribuição da renda e na estratificação social. 
seria (de preferência) um problema de natureza política, ressaltando a importância da análise baseada em conceitos como autonomia, complexidade, coesão e legitimidade das instituições. Por tal dimensão (Huntington et al., 1975, apud Offe, 1984): "a governabilidade de uma Democracia depende do relacionamento entre a autoridade de suas instituiçôes de Governo e da força das suas instituições de oposiçâo"

c) A não-governabilidade poderia ser definida como um conjunto de 1) uma crise de gestão administrativa do sistema, e 2) uma crise de apoio político dos cidadãos às autoridades e aos Governos. Ela seria a soma de uma crise de input e de uma crise de output. Por esta tese (HABERMAS, 1997), as crises de output teriam a forma da crise de racionalidade: o sistema administrativo näo conseguiria compatibilizar, nem agilizar eficientemente, os imperativos de controle que the chegam do sistema econômico. As crises de input teriam a forma das crises de legitimação: o sistema legitimador não conseguiria preservar o nível necessário da lealdade da massa, impulsionando assim os imperativos de controle do sistema econômico que ele assumiu.

Dessa forma, diferentes efeitos sobre a governabilidade são atribuídos à emergência dos mercados globais, desde a eventualidade do fim da capacidade de ação do Estado keynesiano em regular a economia, até uma ameaça ao Estado de bem-estar (Welfare-sate) devido aos efeitos da concorrência global das vantagens locais. Em compensação, há na abordagem conservadora neoliberal uma expectativa de que a mundialização dos mercados traga novos impulsos ao crescimento econômico, à inovação tecnológica e um aproveitamento (realocação) mais eficiente de recursos disponíveis à produçấo (Boito Jr., 1999).

Decorrente disso, a questão da reforma do modelo de Estado passou a integrar a agenda política em nível mundial, a partir dos anos 1980, e é apontada como um desafio necessário devido à crise de governabilidade por que estariam passando os Estados ocidentais, em seus aspectos econômico, 
social e administrativo. Compõe a agenda política destes países o debate sobre a redefinição do papel do Estado e a reestruturaçăo da sua máquina administrativa.

Apesar das visóes divergentes quanto à origem da crise de governabilidade, como se viu, há, porém, razoável consenso (O'CONNOR, 1973, HUNTINGTON et al., 1975, HABERMAS, 1997), ao afirmarem que o Estado (com seus aparelhos ideológicos e administrativos) transformara-se na prineipal referência das atividades políticas dos cidadãos e grupos, e que o fato de ele intervir de maneira crescente e sutil na sociedade incidira sobre as fontes de sua legitimidade.

Além dessas mudanças de força dentro do Estado, houve mudanças de força entre Estados. Um cartel de países do $3^{\circ}$ Mundo tomou cada vez mais difícil a aquisição, a baixo custo, de matérias-primas e de fontes energéticas, introduzindo um fator de forte desequilíbrio na acumulação e distribuição de recursos por parte dos sistemas políticos ocidentais. As graves crises do petróleo de 1973 e 1979 (depois das quais o barril do petróleo passou em média de US $\$ 2,80$ para US $\$ 9,46^{11}$ ) são o exemplo mais acabado desses acontecimentos. Havia chegado ao fím o ciclo econônico mais intenso da hîstória das economias capitalistas, baseado no intenso uso de recurşos naturais de países periféricos, a baixo custo (KURZ 1996). Um dos efeitos políticos dessa crise foi a resistência dos cidadãos e dos grupos organizados dos sistemas políticos ocidentais das economias centrais que, habituados a um crescimento constante e ininterrupto, desde o final dos anos 1950 até o início dos anos 1970 , de improviso, enfrentaram uma parada e, posteriormente, um regresso no seu nível de renda, Para manter afastadas as consequências desagradáveis e aproveitando a possibilidade de participação, cidadãos e grupos fizeram constante pressão junto aos seus respectivos Governos para que os serviços sociais fossem mantidos nos mesmos níveis. Os países capitalistas ocidentais

in Conforme Kucinski e Branford, 1987, p.119. 
sofreram, no anos 1980, os intensos efeitos das mudanças econômicas, cujo principal reflexo foi a inflação, ${ }^{12}$ gerada pela política econômica norte-americana no período: elevação da taxa de juros pelo Federal Reserve, de uma forma sem precedentes (KUCINSKI, BRANFORD, 1987).

Portanto, a crise econômica dos anos 1970 proporcionou espaço para que a teoria econômica neoliberal tivesse uma súbita credibilidade frente ao aparente fracasso do keynesianismo, começando uma escalada em sua hegemonia intelectual e ideológica a partir da vitória política eleitoral conservadora em importantes países de economias centrais, cujos principaís exemplos são os governos Tatcher (GBR, 1979) e Reagan (EUA, 1980).

A resposta encontrada, a partir dos anos 1980 , por quase todos os países capitalistas (em especial os da OCDE) para a crise do Estado foi a adoção de políticas monetárias que propunham a um só tempo combater a inflação e realizar o ajuste do balanço de pagamentos com taxas de câmbio flutuantes, quase sempre acompanhadas de políticas fiscais pró-cíclicas (FIORI, TAVARES, 1993). A receita (a desregulação de mercados financeiros e do trabalho, a desmontagem das fronteiras econômicas nacionais e a privatização das empresas e dos serviços públicos) formatou-se tendo como principal fonte teórica o economista austríaco Friederich von Hayek e, o prêmio Nobel de economia de 1989, Milton Friedman (BOITO JR., op. cit.).

No que diz respeito mais especificamente ao aspecto administrativo, nos anos 1990 , o debate acerca da crise da falta de governabilidade, inserida na chamada Crise de Estado, evoluiu ao ponto de transformar-se em pauta da agenda política mundial: tornou-se uma assembléia geral nas Nações Unidas, o "World Development Report of 1997, The State in a Change World", sendo que seu nome original seria "Rebuilding

\footnotetext{
$12 \mathrm{O}$ combate à espiral inflacionária, em geral, foi prioridade durante este periodo, especialmente na América Latina; no Brasil perdurou até o Plano Real, em 1994.
} 
the State". A partir desta, o Banco Mundial e o Banco Interamericano de Desenvolvimento tornaram prioritários os empréstimos para reforma do Estado. Por consequência, muitos países criaram ministérios ou comissões de alto nível encarregadas de tal tarefa, e da correspondente reforma administrativa do Estado.

Por Reforma de Estado, entende-se o abrangente processo de mudança a que vem sendo submetido o Estado (em especial o Welfare state keynesiano) e que tem redefinido seu modo e suas áreas de atuação na economia, suas formas de intervençẫo na realidade e, sobretudo, seus mecanismos de financiamento. $\mathrm{O}$ objetivo é efetuar mudanças estruturais que habilitem o Estado a conduzir sua sociedade no atual estágio dos mercados integrados, das plantas industriais descentralizadas e da limitada intervenção dos Governos no funcionamento dos mercados (SANCHES, 1997).

As abordagens dos teóricos conservadores sobre a crise (HUNTINGTON, CROIZER, 1975) vêem as causas da nãogovernabilidade nos dispositivos institucionais da democracia de massa do Estado social, apresentando-a como resultado do processo político democrático. O alargamento dos direitos políticos e civis teria se revelado no fracasso estatal em lidar com um excesso de expectativas, não capazes de serem satisfeitas através de seus poderes legais de intervenção. Como solução para o caso, seria exigivel do Estado que aumentasse sua capacidade de direção, e desempenho, e que se aliviasse a sobrecarga sobre o sistema. Essa abordagem é muito seguida, uma vez que foi a adotada pelo Banco Mundial quando financiou países nos programas de reforma do Estado (Rio Grande do Sul, 1995 e 1997; Brasil, 1995).

Por esta análise utilizada, a necessidade de reconstruir o Estado é colocada como exigência da globalizáção da economia e da crise do Estado, e sua tarefa é a de ajudar a indústria a competir nos mercados internacionais e proteger os cidadãos das desigualdades dentro e entre países. O diagnóstico apontado para a crise afirma que sua origem está na 
a) crise fiscal, uma vez que prejudica a capacidade de investimento do Estado; na b) crise do modelo de intervenção do Estado, esgotamento do modelo de welfare state keynesiano, na Europa, e de substituição das importações, na América Latina; e na c) crise do modelo burocrático na administração pública, causa dos altos custos e baixa qualidade dos serviços públicos. (Coutinho, op. cit.)

Quanto à reforma do modelo burocrático, há o pressuposto de que o crescimento do tamanho do Estado (que o leva a ter déficit) é um mal inerente à burocracia, uma vez que os servidores públicos agem apenas na busca da satisfação de seus interesses pessoais (comportamento de rentseeking preconizado pela Teoria da Escolha Pública, abordada na Introdução), o que ocasionaria a tentativa de aumentarem os recursos destinados a seus departamentos para, assim, possuírem cada vez maior poder. Desse modo, apontam as formas de Estado social burocrático como causa da atual crise de Estado, pois gerou a crise fiscal que impediu a sua capacidade de investimento, levando ao mau funcionamento do mercado (PEREIRA, op. cit.).

Produtos dessa direção reformista para a administração do Estado, pró-mercado, tomaram fôlego e passaram a se manifestar cada vez mais no ambiente da administração pública em geral, na gestāo do Estado, seguindo a Nova Administraçấo Pública. São exemplos os programas de Quali-dade Total dentro do serviço público, a preocupação maior com a participação dos cidadãos (agora equiparados a consumidores) na sua gestão, e a adoção de conceitos como "downsizing" e flexibilização.

A fim de analisar a proposta neoliberal apresentada anteriormente, e de se alcançar o objetivo geral do artigo, é fundamental examinar o papel que a burocracia desempenha no Estado capitalista contemporâneo. Para tanto, será utilizada a matriz teórica elaborada pela Escola de Frankfurt, que será abordada a seguir. 


\section{Análise Frankfurtiana da Reforma de Estado}

Para o presente trabalho, como resultado da procura por uma alternativa ao positivismo e ao marxismo, será utilizada a Teoria Crítica, produto da denominada "Escola de Frankfurt". Tal teoria apresenta uma leitura racionalista e emancipatória da sociedade, com reflexôes acerca da razáo e da ciência, a respeito da contemporânea cultura de massas e com preocupações quanto aos problemas estruturais dos estados capitalistas. Considera-se esta abordagem relevante e não convencional para uma temática que abrange cada vez mais aspectos, o que leva a uma ampliação do foco de análise das questōes, chegando até mesmo ao nível filosófico. Os frankfurtianos mais proeminentes, Jüergen Habermas (1994, 1997) Max Horkheimer, Herbert Marcuse (1998), Theodor Wiesengrund-Adorno e Walter Benjamim, são consi-derados filósofos sociais, e suas teorias se constituem na base sobre a qual o referencial teórico da Escola de Frankfurt será construído.

O termo "Fscola de Frankfurt" refere-se simultaneamente a um grupo de intelectuais e a uma teoria social. Com este termo procura-se designar a institucionalização dos trabalhos de um grupo de intelectuais marxistas, não ortodoxos, que se reuniu na década dos anos 1920, e que, a partir de então, permaneceu à margem de um marxismo-leninismo "clássico", seja em sua versão teórico-ideológica, seja na sua linha militante e partidária. Poderíamos defini-la basicamente como um resultado de três fatores: um acontecimento histórico (criação do Instituto de Pesquisa Social - Institut fuer Sozialforschung, em 1923), um projeto científico (Filosofia Social) e uma atitude (a Teoria Crítica).

O objetivo do Institut era institucionalizar um grupo de trabalho para a documentação e a teorização (tendo por base o marxismo) dos movimentos operários da Europa do começo do séc. XX. Na década de 1930 os membros do Instituto efetuaram um estudo empiricamente orientado (Estudos sobre a Autoridade a Familia - Studien zu Autoritaet und Familie, 
1936) que procurou obter informaçốes sobre a estrutura de personalidade da classe operária européia. A pesquisa era relevante, eis que, segundo os teóricos de Frankfurt, essa classe teria perdido a consciência de sua missão histórica, submetendo-se a formas de dominação e exploração totalmente contrárias ao seu interesse emancipatório. A busca de uma integração da teoria marxista com o freudismo constituiu a preocupação central do trabalho e uma vertente central dos membros da Escola desde entấo.

A abordagem psicanalítica se justificava, portanto, para se elaborar uma teoria social que deveria partir do indivíduo. ${ }^{13}$ Este, por sua vez, não era mais concebido do mesmo modo que os iluministas, como um ser plenamente consciente de seus atos e racional em todas suas escolhas na vida uma vez educado. Foi redefinido a partir dos trabalhos da psiquiatria, que definiu o papel do inconsciente nas atitudes do ser

13 Marcuse (1998, p.94), posteriomente, argumentou da obsolescência do próprio modelo psicanalítico clássico para analisar a sociedade contemporânea. Conforme tal modelo, o pai e a familia dominada pelo pai eram o agente da socializacăo psíquica do indivíduo, contudo, estes perdem seu valor, uma vez que a sociedade passou a agir diretamente, através dos mass media, dos agrupamentos escolares e esportivos, dos bandos de jovens etc sobre o ego que esta se constituindo. Esse decínio do papel do pai sucede à decadencia da empresa privada e familiar: o fliho é cada vez mais independente do pai e da tradicão familiar na scolha e na procura de um posto de trabalho e na maneita de ganhar a vida. As obrigacoes e o comportamento socialmente necessários jấ não são aprendidos - interiorzados - na longa luta com o pal o ldeal do ego é muito mais levado a agir diretamente e "de fora" sobre 0 ego, antes ainda que este tenha se constituido de fato comó sujeito pessoal e (relatvamente) autonomo da mediacaao entre o próprio eu e os outros Como consequéncia, dá-se a formaçao das massas, cujos traços conforme Freud, sao: "desaparedimento da personalidade individual consciente, orientaça dos pensamentos e senúmentos na mesma direcá, preponderancia da afetividade e da vida psiquica inconsciente tendencia a executar inediatamente as intencôes que surgem. (MARCUSE, op cit, p.97). Marcuse pontua que os sinais de regressáo da consciéncia de nndivíduo a consciência de bando, constatados por Freud, parecem poder ser observados de fato nos domínios da avançada sociedade industrial: a antena em cada casa, o rádio em cada praia, a vitrola em cada bar e restaurante são todos gritos de desepero para nao ficarmos sos, separados dos grandes, condenados ao vazio, ao ódio ou aos sonhos do próprio eu". A consciência moral e a responsabilidade pessoal degeneram "objetivamente" sob as condiçôes da burocratização total, nas quais extremamente dificil atribuirse ainda uma autonomia em que o funcionamento do aparato detemina a autonomia pessoal, pondo-se acina dela. Esta discussão terá profundos reflexos na teoria de comunicação de massas. 
humano, como dos impulsos irracionais, sobretudo a libido, urgência de morte, as manifestaçōes neuróticas etc. (JAY, 1986)

O estudo acerca da autoridade influenciou decisivamente no redirecionamento do interesse original do Instituto, de documentar como a classe operária enfrentava as crises específicas do capitalismo do começo do séc. XX para um interesse teórico de se descobrir o porqué de a classe operária náo ter assumido o seu destino histórico de revo. lucionar a ordem estabelecida. Essa explicação era buscada na conjugação das macroestruturas capitalistas com as microestruturas da familia burguesa e proletária.

Para uma abordagem mais completa quanto à origem da Escola de Frankfurt, a passagem de suas fases (fundaçäo, exilio e volta à Frankfurt), o desenvolvimento de suas idéias, bem como do alcance da Teoria Crítica: vide Assoun (s.d), Freitag (1994), Jay (1986).

\subsection{Estado e economia sob a perspectiva da Teoria Crítica}

A Teoria Crítica apresenta falta de critérios válidos para conseguir enquadrála em seu conjunto, uma vez que ela năo tem para si própria nenhum outro requisito específico a não ser o interesse das massas na supressão da injustiça social, em função da qual se define. Apesar disso, o conteúdo teórico dos trabalhos dos autores frankfurtianos orbitaram (sem unidade) em tomo de trếs eixos temáticos: 1) a dialética da razão luminista e a crítica da ciência, 2) a dupla face da cultura e a discussão da indústria cultural; ${ }^{5}$ e 3) a questão do Estado e suas formas de legitimaçăo Este terceiro eixo

\footnotetext{
14 Oprograma do Iluminismo consistia no desencantamento do mundo. Os iluministas queriam dissolver os mitos e fortalecer as impressóes atraves do saber Mas o saber produrado pelo liuminismo náo conduziu a emáneipacáo e sim â tecnica e a céncia modernas, que mantem como seu objeto (o homem e a natureza) uma relaçao ditatorial.

15 A Escola de Frankfurt contribuiu de forma decisiva para o desenvolvimento e 0 estudo da comunicação (de massas), sobretudo através dos trabalhos de Jürgen Habermas. Este pontua que na sociedade industrial moderna, o divorcio entre os
} 
conduzirá o estudo, a partir daqui, para que sejam abordadas as implicações da forma de atuação burocrática no Estado capitalista contemporâneo. Será abordado, decorrentemente, o aspecto da intervençäo do Estadó na economia

Os teóricos de Frankfurt abordaram o crescente intervencionismo estatal na economia e ressaltaram a tese de que nenhuma economia industrializada modema - fosse ela capitalista ou socialista - seria capaz de dispensar a grande presença reguladora do Estado. (Marcuse, op. cit., p. 116). Com base em reflexões resultantes da análise das causas e conseqüências das Duas Grandes Guerras, acordaram que o Estado nacional năo mais poderia assumir a postura de mero espectador da livre dinâmica das forças econômicas, preconizado pelo pensamento liberal.

Caberia a ele uma progressiva e crescente participaçäo na gestão da economia nacional, e também na manutenção do equilíbrio internacional, uma vez que a livre concorrência não apresentava mais condições de servir como princípio regulador da economia nacional, devido ao fato de ela ser válida numa fase em que as crises se limitavam à falência

modos de vida $e$ as verdadeiras aspiraçöes humanas é täo grande, que um novo gênero de repressão suplementar (diferente do medo de perder o emprego ou status) se faz necessário: a moldagem da psique. A própria vida subjetiva se toma objeto de manipulação e controle, sobretudo no nivel do inconsciente (MERQUIOR, 1969, p.27) A nova produção cultural não é, pois, simplesmente mais um ramo da produção na diversificada produçăo capitalista, ela fôl concebida e reorganizada para preencher funçoes sociais especfficas, antes preenchidas pela cultura burguesa; alienada de sua base material. A nova produçấo cultural apresenta a função de ocupar o espaço do lazer que resta ao operáno e ao trabathador assalaniado depois de um longo día de trabaiho, a fim de recompor suas forças para voltar a trabalhar no dia seguinte, sem the dar trégua para pensar sobre a realidade miserável ern que vive. A indústria cultural, além disso, cria a ilusão de que a felicidade não precisa ser adiada para o futuro, por já estar doncretizada no presente. (Freitag, op. cit., p.72) As massas são sugestionadas para consumirem incessantemente, pois o consumo é apresemtado como o caminho para a realizaçäo pessoal. Assim, a cultura fornecida pelos meios de comunicaçăo de massa näo permite que as classes assalariadas assumam uma posição crítica face a sta realidade, já que ela mistura os planos da realidade material com as suas fomas de representaçăo e, progressivamente, anulam os mecanismos da reflexäo e crítica para acionarem a percepçăo e os sentidos. 
de um ou outro empresário, nas quais não havia riscos para a sobrevivência do modo de produção capitalista. Contudo, deixara de servir quando se tratava de assegurar o sistema como tal, já organizado em enormes cartéis que rapidamente transcendem limites geográficos da naçắo, e instabilizam o sistema econômico em nível mundial. Assim, para os teóricos de Frankfurt, o capítalismo contemporâneo imporia ao Estado a necessidade de intervir sistematicamente no processo econômico a fim de salvaguardar a própria economia nacional e com isso a sobrevivência da naçăo, contribuindo, por reflexo, para a manutenção do sistema econômico mundial.

Offe (1977), analisando o papel do Estado na sociedade industrial capitalista contemporânea, procurou identificar quais as estruturas e os mecanismos que geram a continuidade desta, e sua identidade. Pontuou que:

[.. a sociologia resolve esse problema primordial [...] na medida em que indica quais são exatamente as questōes estruturais que problematizam o contexto societário e sua continuidade histórica, e esclarece através de que medidas de "integração" o sistema social é capaz ou não de resolver os seus problemas estruturais específicos (OFFE, 1984, p.14).

O principal problema estrutural identificado não é outro que aquele apontado por Marx, ou seja, os interesses opostos entre os componentes mais característicos do modo de produção capitalista: a mais-valia e a mercadoria, ou o operário e o capitalista. ${ }^{16}$

O capital produz essencialmente capital e, para fazê-lo, não tem outro caminho a não ser produzir mais-valia. Ao examinar a transformação da mais-valia em lucro (necessário para reinvestir e aumentar a produção) Marx (1947) coloca que tal processo age em contraposiçäo direta ao

\footnotetext{
1s $\mathrm{Na}$ análise marxista, estão ao mesmo tempo na essência do capitalismo a mais-valia, que funda a acumulação de capital, e o proletañado, que produz a mais-valia.
} 
próprio desenvolvimento do trabalhador, uma vez que há na produção da mais-valia...

[...] a tendência constante a reduzir o tempo de trabalho necessário para produção de uma mercadoria, isto é, seu valor, a um limite inferior à média social vigente em cada momento. A tendência a reduzir o preço de custo a seu mínimo se converte na mais poderosa alavanca para a intensificação da força produtiva social do trabalho, que sob esse regime, só aparece como intensificação constante da força produtiva do capital. ${ }^{17}$

O sistema capitalista de produção cria seus produtos com caráter de mercadonia, aparecendo, inclusive, o próprio trabalhador como vendedor de mercadoria (trabalho) mediante pagamento de salário. Assim, 'a determinaçấo valorativa e a regulação da produçăo total dá-se pelo valor da mercadoria. O trabalho, como trabalho social, fica com sua distribuição regulada pela

[...] ação fortuita dos diversos produtores capitalistas, ação na qual as tendências de uns, destroem as de outros e vice-versa. Como esses produtores só se enfrentam enquanto possuidores de mercadorias, e cada um deles procura vender a sua pelo mais alto preço possivivel ( $e$, alêm disso, aparentemente; só é governado por seu arbítrio na regulação da própria produção), resulta que a lei interna só se impõe por meio de sua concorrência, da pressão mútua exercida por uns sobre os outros, o que faz com que as divergências sejam reciprocămente compensadas. (Marx, apud Ianni, 1987, p.77).

O problema é que não há garantias confiáveis suficientes para integração de um sistema social baseado estritamente nestes moldes, no qual os mecanismos de regulação e controle social säo gerados apenas pelo mercado. Este

\footnotetext{
${ }^{7}$ Marx, K. Características Esencidles del Sistema Capitalista. In: El capital México, Fondo de Cultura Económica, 1947, t. III cap. II, p. 1013-20. Trad por Mara Elisa Mascarenhas, apud Ianni, 1987, p.78.
} 
apresenta uma crescente tendência de concentração de capital, expropriando aqueles indivíduos que não são capazes de integrar o mercado de trabalho. Além disso, o trabalho assalariado impõe sistemas de remuneração baseados no desempenho, colocando, muitas vezes, os trabalhadores sob pressão de situaçōes de emprego que podem ser prejudiciais à sua saúde: manejo de instalaçôes perigosas, não observância de regras de segurança, ritmo de trabalho prejudicial, jornadas de trabalho excessivamente longas.

Além dessa impotência dos trabalhadores frente às exigências do trabalho assalariado na produção industrial, deve-se acrescentar que também...

[...] as empresas só podem ter uma consideraçâo limitada com a saúde e a integridade corporal do operário. Danificada a força de trabalho de um empregado, os empresários reagem, via de regra, com a demissão e a contratação de força de trabalho mais eficaz. Assim, há poucas razões para que as empresas adotem espontaneamente medidas preventivas para proteger o trabalho, ou renovar a força de trabalho. Por outro lado, o valor de mercado da força de trabalho e restringido pela constante obsolescência da qualificação profissional. O contexto funcional autonomizado das inovações técnicas e organizacionais e a concorrência recíproca dos que oferecern sua força de trabalho provocam um desequilibrio permanente, não superável no contexto de mercado, entre a estrutura do empregado e as capacidades individuais (OFFE, 1984 , p.21).

Portanto, estas formas de aproveitamento implicam a não consideração dos limites da resistência (física e psíquica) dos trabalhadores, no interesse de preservar de forma permanente a capacidade de trabalho. Isso quer dizer que o sistema social que é estruturado pelo modelo capitalista, por si só, näo fomece as necessárias medidas de integração que permitam sua repródução social e continuidade histórica. Para que tal ocorra, faz-se necessário que a forma de organização 
do trabalho assalariado seja imposta por mecanismos "ideológicos" e "repressivos" do Estado. ${ }^{18}$

Dentre estes, identificou Offe (1977), como principal mecanismo de integração a Política Social, caracterizando esta como: "a forma pela qual o Estado tenta resolver o problema da transformação duradoura de trabalho não assalariado em trabalho assalariado". O processo de industrialização capitalista é acompanhado de processos de desorganização e mobilização da força de trabalho, fenômeno que năo se limita à fase inicial do capitalismo, mas que nela pode ser observado com especial clareza. (Esses processos podem ser verificados, atualmente, também com a globalização.)

A ampliação das relaçöes concorrenciais aos mercados nacionais e finalmente mundiais, a introdução permanente de mudanças técnicas poupadoras da força de trabalho, a dissolução das formas agrárias de vida e de trabalho, a influência de crises cíclicas, etc. têm o efeito comum de destruir, em maior ou menor medida, as condições de utilização da força de trabalho até então dominantes. Os individuos atingidos poî tais processos entram numa situação na qual não conseguem mais fazer de sua própria capacidade de trabalho a base de sua subsistência, já que não controlam, seja em termos individuais ou coletivos, as condiçōes de utilização dessa capacidade. Isto não quer dizer de forma alguma que esses individuos por si mesmos tenham condiçōes de descobrir; para enfrentar esses problemas, a solução específica que consiste em alienar a terceiros sua força de trabalho em troca de dinheiro, isto é, de aparecerem no mercado de trabalho, do lado da oferta. (OFFE, 1984; p.15)

\footnotetext{
${ }^{18}$ Para que haja a socialização dos trabalhadores segundo o modelo de mercadoria. säo requeridos elementos ideológicos nesse processo, isto é, os trabalhadores precisam ter motivos culturais para se transfomar em trabalhadores assalariados. A força de trabalho precisa estar disposta a oferecer sua capacidade de trabalho no mercado como uma mercadoria e aceitar os riscos e as sobrecargas associadas a essa forma de existência como relativamente suportáveis. Tal tema tem sido trabathado por estruturalistas franceses. (OFFE, op. cit.)
} 
Desde a origem do processo de industrialização, é necessária a participação ativa do Estado, uma vez que é impossível a passagem em massa de uma força de trabalho despossuída (dos meios de produção) em trabalho assalariado sem uma política estatal (que, por sua vez, abarque a política social). ${ }^{19}$ Ou seja, precisam constituir-se condições sócioestruturais para que o trabalho assalariado se generalize e funcione efetivamente, já que, em vista das condiçổes especiais de vida, nem todos os membros da sociedade podem funcionar como trabalhadores assalariados, a menos que certas funçōes de reproduçẩo elementares (especialmente na área da socialização, da saúde, da formação profissional e da assistência à velhice) deixem de ser preenchidas. Portanto, tornam-se necessánias medidas institucionais especiais, sob cuja proteção parte da força de trabalho fica dispensada, por assim dizer, da pressão de se vender, sendo consumida de outra forma que pela cessão em troca de dinheiro (como o caso da dona-de-casa). Offe (1977) acrescenta que, então, é funcionalmente indispensável que existam subsis-temas externos ao mercado, isto é, que não sejam regidos pela lógica do lucro, como a família, a escola e instalações de assistência à saúde, para que o sistema tenha condições de se estabilizar em uma sociedade.

O porquê da institucionalização (e estatização) daqueles, por via da política estatal, está no fato de que os subsistemas da fase pré-industrial (Igreja, família, caridade) perderam eficiência no sistema com o decorrer do tempo, demonstrando a necessidade da sua formalização jurídica, a fim de

\footnotetext{
' Offe (1977) acrescenta que a aceítação por si sô de tal processo, de modo automá. tico, transforma em uma evidência sociológica o que é apenas o "caso geral" do desenvolvimento histórico, e tende a levar a perder de vista os mecanismos que precisam existir para que o próprio "caso geral" de fato venha a ocorrer. A socialização em massa das forças de trabalho como trabalho assalariado e mesmo o surgimento de um mercado de trabalho năo são tão bbvias e "naturais" assim. Ou seja, para que se de o processo de industrialização (capitalista) é necessário que condiçôes sócio-estruiurais estejam presentes para que efefivamente funcione, e se perpetue, o sistema baseado no trabalho assalariado.
}

Cadernos do PPG em Direito UFRGS, Porto Alegre, v. 6, n. 7 e 8, p. 103-150, 2007. 
garanti-los. Somente a estatização daqueles subsistemas pôde controlar (administrar) as condições de vida, e de acesso, relativas à sítuação de se estar fora do mercado e sendo sustentado, uma vez que o Estado só pode organizar diretamente os desempregados em escala muito limitada (serviço militar, frentes de trabalho, reciclagem profissional), mas pode mobilizar os papéis sociais tradicionais, a fim de usá-los para regulação quantitativa do mercado de trabalho.

Assim, a tarefa da Política Social é garantir a reprodução material e controlar o assalariado, com o Estado definindo quem é trabalhador, e preservando a existência do șistema baseado no trabalho assalariado. Com isso, permite-se obter. uma correspondência quantitativa aproximada entre o número de indivíduos proletarizados (de forma passiva) e aqueles que podem encontrar ocupação como trabalhador assalariado, em vista da demanda do mercado de trabalho (ou seja, fornece condiçōes para a busca keynesiana do pleno emprego).

Outra vantagem considerável para o capital e sua capacidade de absorver trabalhadores assalariados está em que somente um sistema de seguro social permite que a figura do "trabalhador médio", depurada de todas as contingências, se transforme na base de cálculo para a gestão racional da empresa (racionalizaçäo da administração). A situação pessoal, a idade, a dimensão da família, o estado de saúde etc. da força de trabalho empregada, não precisam ser considerados pela empresa, já que as conseqüências materiais de tais especificidades concretas podem ser assumidas fora do processo empresarial $e$, de qualquer modo, näo repercutem de forma imediata em reivindicações salariais.

Resumindo, uma vez que o grau de rentabilidade da mão de obra é rebaixado pelo sistema, faz-se necessário um sistema de amparo externo ao mercado de trabalho (sendo ditado pelo Estado sua forma de prestação e seus destinatários, isto é, quem tem direito). Para que funcione tal sistema, é necessária a atuação do Estado, via burocracia estatal. Portanto, "só a organização burocrática estatal permite ajustar de forma flexivel as 
medidas politico-sociais às exigências da economia de mercado" (OFFE, 1984, p.30), através do instrumentário das políticas sociais e mediante critérios econômicos e jurídicos.

A política social representa uma estratégia estatal de integração de força de trabalho na relação de trabalho assalariado, isto é, uma relação que somente poderia adquirir a difusäo e a normalidade" que hoje existem graças à efetividade dessa estratégia. Neste sentido a política social não é mera 'reação' do Estado aos 'problemas' da classe operária mas contribuiu de forma indispensável para a constituição dessa classe. A função mais importante da política social consiste em regulamentar o processo de proletarização. (OFFE, 1984, p.22)

\subsection{Critica da reforma neoliberal}

Com base na análise desenvolvida até aqui, é pertinente avaliar criticamente a proposta neoliberal de reforma de Estado. A abordagem crítica acerca da crise do Welfare state (OFFE, 1977, HABERMAS, 1975), aponta como causa da ingovernabilidade, e da crise fiscal, do Estado capitalista a incompatibilidade natural entre as duas funçōes do Estado assisten cial: o fortalecimento do consenso social, da lealdade para com o sistema das grandes organizações de massa; e o apoio à acumulação capitalista com o emprego anticonjuntural da despesa pública. O Estado assistencial traria como resultado a estatizaçăo da sociedade, uma vez que o Welfare state dispersaria, parcialmente, os motivos e as razôes do conflito social, enquanto tornaria aceitável a existência de trabalho assalariado ao eliminar parte do risco que resulta da imposição da forma de mercadoria ao fator trabalho. Contudo, essa lógica de procedimento vai de encontro a própria lógica capitalista.

Exige-se que a Política Social garanta a reprodução material do capitalismo (via crescimento econômico) ao mesmo tempo em que preserve o sistema baseado no trabalho assalariado (via reprodução da mão-de-obra). Aqui cabe colocar que, para Offe (1977), a lógica estrutural concentradora, com 
produção e consumo exacerbados de mercadorias, leva a uma tendência de acumulação ampliada que exige mais exploração da força de trabalho. Desse modo, a exigência de uma acumulação ampliada, com manutenção e progressivo aumento da taxa de lucros do empreendimento para se manter num mercado globalizado de forma competitiva, é construída sobre o sacrifício e a exploração irracional da força de trabalho, rompendo o concerto encontrado pelo welfare state keynesiando. Tal concerto poderia ser entendido como um

[...] acordo [que] representou, por parte da máo-de-obra, a aceitação da lógica do lucto e dos mercados como princípios orientadores da alocação dos recursos, das trocas internacionais, da mudança tecnológica, do desenvolvimento do produto e da localização industrial, em troca de uma garantia de que seriam defendidos os padróes mínimos de vida, os direitos sindicais e os direitos democráticos liberais, seria evitado o desemprego em massa e a renda real subiria aproximadamente de acordo com a produtividade do trabalho, tudo isto através da intervenção do Estado, se necessário. (Bowles, apud Offe, 1984, p.372)

Pode-se afirmar, pois, que o welfare state keynesiano numa sociedade capitalista, dispersa, parcialmente, os motivos e as razões do conflito social, enquanto torna mais aceitável a existência do trabalho assalariado ao eliminar parte do risco que resulta da imposição da característica de mercadoria ao fator trabalho. Contudo, este concerto, como foi visto, teve suas limitaçồes explicitadas a partir das mudanças do ambiente econômico verificadas em meados dos 1970. Em tal ambiente, longe de estimular mais a produção, a prática dos governos ocidentais de promover déficits a fim de combater o desemprego contribuiu para taxas ainda mais altas de desemprego - colocando em evidência a teoria econômica conservadora liberal e o "neo-laissez-faire" (OFFE, 1983). 
O Welfare state keynesiano, portanto, seria uma vítima do seu sucesso (OFFE, 1984, p.379). Pelo fato de eliminar (parcialmente) e acomodar as crises cíclicas do capitalismo, ele inibiu a função econômica positiva que as crises geralmente desempenhavam no processo capitalista da destruiçâo criativa, ${ }^{20}$ não incentivando o investimento nem a inovação no trabalho. Assim percebe-se que os princípios do Welfare state seriam incompativeis, diretamente, com um sistema de mercado capitalista, sendo que a sua principal contradiçấo é a tensão entre o mercado e a política social. A proposta neoliberal de reforma de Estado faz uma clara opção pelo mercado, tensionando ainda mais as relaçōes da sociedade e reativando suas contradiçōes.

Tal tensão evidencia que os dois mecanismos institucionais sobre os quais repousa a compatibilidade da economia privada e da participação política das massas - a saber, o mecanismo da democracia partidária competitiva e $\mathrm{o}$ paradigma do welfare state keynesiano - estão sob tensões de pressões cuja ordem de magnitude não tem precedentes no após-guerra. (Offe, 1984, p.382)

Ocorre que as políticas sociais do Welfare state parecem contribuir para um parcial desestímulo ao trabalho, uma vez que seus esquemas de seguro social compulsốrio oferecem uma proteçäo institucional aos interesses materiais dos trabalhadores assalariados e que a mão-de-obra torna-se menos preparada e/ou pode ser menos facilmente forçada a se ajustar às contingências das mudanças estruturais, tecnológicas, de locação e outras da economia. Como o Estado intervém no processo macroeconômico, via atuação burocrática também, o crescimento econômico torna-se assunto do designio político, ao invés de ser matéria das forças "espontâneas" do mercado.

\footnotetext{
20 A crise tem um efeíto de retirar da economia empresas não eficientes, cujo património tende a ser adquirido por empreendimentos maiores. Tais empreendimentos disporiam, assim, de uma maior capacidade para investimentos, que financiaria um aumento de produça e de produtividade, alimentando o crescimento do ciclo econômico.
} 
A política social, assim, solapa os incentivos ao investimento (e ao trabalho), afetando o crescimento econốmico, como foi reconhecido nas palavras de um representante da social-democracia européia:

\begin{abstract}
Élamentável que aqueles que desejam defender o welfare state... gastem suas energias persuadindo o público de que o welfare state não solapa os incentivos, as poupanças, a autoridade ou a eficiência.. O que a direita reconheceu muito melhor do que a esquerda é que os princípios do welfare state são incompativeis, diretamente, com um sistema de mercado capitalista... [...] O welfare state morde a própria mâo que o alimenta. A sua principal contra diçấo é à.. tensão entre o mercadó e a política social. (EspingAnderson, apud Offe, 1984, p.379).
\end{abstract}

Desse modo, parece que uma opção pura e simples prómercado, em detrimento da execução (via atividade burocrática estatal) das funçôes da Política Social, apresentaria a tendência de levar o Estado à situação de crise semelhante àquela enfrentada pelo Estado liberal no início do séc. XX, crise esta que deu origem, como resposta, ao Welfare State keynesiano.

\title{
5 Conclusão
}

Conforme foi citado na Introduçăo deste artigo, o seu objetivo foi o de demonstrar que qualquer proposta de reforma de Estado, que tenha por fim aumentar sua governabilidade (e a governança), por meio de uma maior eficiência na atuação e na prestação dos serviços públicos, com reflexo na melhoria das condições de vida da população, não pode passar apenas pela dimensão técnica da forma de atuação do Estado, mas também por questốes epistemólógicas e por reformulação dos princípios da ação estatal.

Dessa forma, acredito que o objetivo geral foi alcançado a contento, uma vez que foi trabalhado neste artigo a crise de governabilidade por que está passando o Estado capitalista contemporâneo, na sua forma mais característica nos países 
democráticos ocidentais, ou seja, no Estado de Bem Estar Social. Este se caracteriza como aquele garantidor de tipos mínimos de renda, alimentação, saúde, habitação, educação, assegurados a todo cidadão, não como caridade, mas como direito político (REGONINI, in BOBBIO et al., op. cit., p.416).

Foi abordado que tal crise apresentou conseqüências no modelo de desenvolvimento dos países ocidentais: o rompimento do consenso keynesiano na Europa, e do modelo de substituição das importaçōes, na América Latina. Apresentaram-se, ainda, as principais características do Welfare state: atuação do Estado na economia, via políticas keynesianas e políticas sociais: e forma de atuaçấo do Estado via organização burocrática weberiana.

O choque na economia mundial provocado pela Crise do Petróleo, na década de 1970 , abriu espaço para que se tomasse hegemônica a interpretação conservadora neoliberal da crise de Estado, com tendência pró-mercado. Esta orientação apresenta um diagnóstico no qual se aponta como principal causa da não-governabilidade os dispositivos institucionais da democracia de massa do Estado social (HUNTINGTON, CROZIER, 1975; apud OFFE, 1984), além da crise fiscal (O'CONNOR, apud PASQUINO et al, 1997). O alargamento dos direitos políticos e civis teriam se revelado no fracasso estatal em lidar com um excesso de expectativas por parte das populaçôes dos países, incapazes de serem satis feitas através de seus poderes legais de intervenção.

A solução apresentada pela corrente neoliberal seria aumentar a capacidade de direção e desempenho do Estado, com o correlato alívio da sobrecarga de expectativas sobre o sistema. O caminho, cuja base teórica é a Teoria da Escolha Pública, seria a diminuição do tamanho do Estado, a desregulação da economia, o aumento da governabilidade e da governança. Esta entendida como a capacidade de o Estado tomar decisôes efetivas que englobaria o ajuste fiscal, a administração gerencial (Nova Administração Pública) e a separaçăo 
entre os órgãos que formulam e os que imple-mentam as políticas públicas (COUTINHO, 2000; PEREIRA, 1997).

Então, para resolver seu problema de não-governabilidade, o Estado de Bem-Estar Social deveria agir de forma diferente: na economia, passar de políticas keynesianas e sociais para políticas monetárias e fiscais pró-cíclicas; e na questăo administrativa, quanto a sua forma de atuação, passar de um modelo burocrático para um gerencial,

Contudo, a atual hegemonia ideológica, neoliberal ou pró-mercado, que se tem manifestado nos processos de reforma de Estado, sobretudo na questão administrativa, parece não dar conta dos diferentes princípios da açâo que apresentam o ambiente público e o privado. A Administração Gerencial teve origem na iniciativa privada, em que algumas empresas obtiveram estrondoso sucesso implantando programas que valorizavam, sobretudo, as necessidades dos clientes. Grosso modo, tais inovaçôes passaram a ser conhecidas como Programas de Qualidade (TIRONI et al., 1991). O setor privado pauta-se pela lógica individual do mercado capitalista (racionalidade instrumental), que procura minimizar as perdas e maximizar os ganhos, transformando a maisvalia em lucro, e nesse processo não tem qualquer preocupação com á reprodução do fator trabalho, isto é, da mãode-obra. O problema é que não há garantias confiáveis para a integração de um sistema social baseado estritamente nestes moldes, no qual os mecanismos de regulação e controle social são gerados apenas pelo mercado (OFFE, 1984).

Em contraposiçăo, o setor público em um Estado de BemEstar Social pauta-se por uma lógica de Política Social, cujo objetivo é a garantia da reprodução material e do controle da classe trabalhadora, preservando a existência do sistema baseado no trabalho assalariado. Isso quer dizer que, uma vez que o grau de rentabilidade da mäo-de-obra é rebaixado pelo mercado, faz-se necessário um sistema de amparo externo ao mercado. Para que tal sistema social funcione, é necessária a atuação do Estado, via burocracia estatal. 
Esta análise pode ser realizada através da "Teoria dos Sistemas" de Luhman, trabalhada pela Escola de Frankfurt. Primeiramente, consideremos um Estado capitalista, de forma hipotética, como um sistema fechado com capacidade de autoorganizaçáo, ou seja, em que exista uma circularidade necessária e suficiente entre seus elementos para que toda e qualquer operacionalizaçáo com vistas à manutenção do próprio sistema se realize a partir de seus próprios componentes. Este sistema, se fosse inteiramente regido pela lógica do mercado capitalista (do lucro) não poderia permanecer no tempo, uma vez que há uma contradição inerente no modo de produção capitalista, qual seja, os interesses opostos entre os seus componentes mais característicos: o trabalho e o capital, ou o operário e o capitalista.

Tal sistema apresenta, por característica, uma crescente tendência de concentração de capital e um rebaixamento do valor do fator trabalho, não fornecendo as necessárias medidas de integração que permitam sua reprodução social e continuidade histórica, ou seja, não apresenta por si só uma racionalidade sistêmica. Para que esta se faça presente, faz-se necessário um subsistema destinado a garantir a permanente integração da força de trabalho no sistema, permitindo a reprodução da mão-de-obra, a manutenção do trabalho assalariado e do sisterna capitalista.

Este subsistema não é outro que a própria Política Social, que age por meio da administração estatal. A sua presença é a principal característica do Welfare state, que se caracteriza como sendo o garantidor de níveis mínimos de condições de vida a todo cidadão como direito polííco. Assim, o subsistema de Política Social no Estado capitalista contemporâneo, por se pautar pela racionalidade de direito político, não atua conforme a lógica do mercado.

Sendo assim, pretende-se ter demonstrado que, a priori, a firn de atacar a crise de governabilidade do Estado capitalista contemporâneo, na sua forma de Welfare state keynesiano, não basta simplesmente adotar-se a racionalidade do mercado, a 
lógica do sistema produtivo, uma vez que esta por si só não fornece a medida necessária de integração social que permita sua manutenção no tempo (racionalidade sistêmica). Portanto, pelos argumentos expostos conclui-se que a adoção da lógica da empresa privada, bem como sua simples generalização no ambiente estatal, não se apresenta como uma alternativa viável no futuro para a crise de governabilidade do Estado capitalista contemporâneo.

Por fim, aqui cabe traçar algumas consideraçōes de ordem pessoal quanto às reformas na Administração Pública. Apesar de posicionar-me de forma crítica às reformas neoliberalizantes do Estado, integro o serviço público desde 1994 e tive tempo suficiente para perceber a real ineficiência do Estado brasileiro e o desperdício de recursos, ocasionados por problemas tanto da burocratização (disfuncionalidade da instituição) quanto, sobretudo e paradoxalmente, pela falta de burocracia (e o que esta sugere, sistema de mérito, racionalidade, impessoalidade, clara definiçăo de atribuições etc.). É inegável que tais problemas devam ser enfrentados, porém, acredito que os instrumentos utilizados devam sempre ser adaptados com rigor para o âmbito público, procurando-se pensar nos seus efeitos futuros para a sociedade e conseqüências para as instituições estatais.

A tendência hegemônica atual (Administração Gerencial) apresenta uma fortíssima influência dos países anglo-saxổes, cujas características culturaís e de Estado, Política e Direito são bem diversas das brasileiras. A simples transposição de instrumentos para o ambiente nacional, como se fossem moldes para a realidade e sem mediaçäo alguma com nossa cultura política, parece ser uma tática fadada ao insucesso, além de dificultar ainda mais qualquer tentativa razoável e séria de reforma.

Creio que, em lugar de se deslumbrar com fómulas prontas advindas da iniciativa privada ou de "consultorias", a Administração Fública brasileira deve repensar a sua açăo burocrática, com seus pressupostos e consequuências. Deveriam 
ser mantidas aquelas características que são positivas e necessárias: um sistema de ingresso e ascensão baseado no mérito pessoal e com critérios objetivos (projeto nunca implantado em sua plenitude na nossa sociedade, de larga tradição clientelista e patrimonialista); uma atuação conjunta do aparelho do Estado e que apresente racionalidade (com uma ordenação de órgãos e atos estabelecida de forma que conduza a objetivos claros previamente fixados, com todas as partes da estrutura apresentando um papel funcional com respeito a finalidade prevista), e atuaçâo sujeita às leis e normas (não às vontades subjetivas do superior, seja um burocrata ou político).

Por outro lado, devern ser combatidas as características negativas da burocracia. A fim de exemplificar, citarei sua principal disfunção estrutural: a incapacidade de reflexâo sobre a própria atividade que desempenha. Devido, dentre outros fatores, à rígida divisâo entre aqueles que decidem e os que executam as ações (e à conseqüente disjunção entre as premissas da ação e o aparelho que as exccuta) a organizaçâo burocrática não é capaz de tematizar suas próprias premissas; quando o faz, náo consegue reverter em benefíciós para a atualizaçăo da estrutura. A eficiência é vista como rígido cumprimento das normas estabelecidas, e não como execução da funçăo previamente definida ou a resolução eficaz de um problema social, por exemplo. Há uma maior preocupaçăo quanto aos meios do que aos fins.

Para tal problema, hâ realmente várias técnicas disponíveis à Administração Pública Contudo, reafirmo, a simples transposiçấo de instrumentos para o âmbito estatal, sem qualquer reflexão ou mediação, abordando-se somente a dimensão técnica da forma de atuação do Estado de maneira descontextualizada năo se apresenta, sob minha óptica, como alternativa viável para tornar o Estado mais eficiente. 


\section{Referências}

ABRUCIO, Femando; COSTA, Valeriano Mendes Ferreira. Reforma de Estado e o Contexto Federativo Brasileiro. São Paulo: Fund. Konrad-Adenauer. 1998. (Série Pesquisas n. ${ }^{\circ} 12$ )

ANDREWS, Christina e W., KOUZMIN, Alexander. Dando Nome à Rosa: o Discurso da Nova Administraçäo Pública no Contexto Brasileiro. Disponível $\mathrm{em}$ : < http://www.feasp. usp.br/fundacoes/reforma/textos.htm>. Acesso em: março de 2000 . (Uma versāo anterior foi apresentada na XI Conferência National da Public Administration Network, realizada em Colorado Springs (EUA) em março de 1998).

ASSOUN, Paul-Laurent. A Escola de Frankfurt. São Paulo: Ática. (s.d.)

BASTOS, Celso Ribeiro. Curso de Direito Constitucional. 16. ed. São Paulo: Saraiva. 1994. 400p.

BINETTI, Saffo Testoni. Iluminismo. In: BOBBIO, Norberto; MATTEUCCI, Nicola; PASQUINO, Gianfranco et al. Dicionário de Política, trad. Carmen C. Varriale et al., 10. ed. Brasilia: Universidade de Brasilia. v. 2. 1997. p. 605 611.

BRASIL, Presidência da República, Câmara da Reforma do Estado. Plano Diretor da Reforma do Aparelho do Estado. Brasília: Ministério da Administração e Reforma do Estado. 1995.

BOBBIO, Norberto; MATTEUCCI, Nicola; PASQUINO, Gianfranco et al. Dicionário de Política, trad. Carmen C. Varriale et al. 10. ed Brasília: Universidade de Brasilia. v. 2. 1997.

BOITO Jr., Armando. Política Neoliberal e Sindicalismo no Brasil. Sāo Paulo: Xarnă. 1999.

CHIAVEnATO, Idalberto. Administração - Teoria, Frocesso e Prática. São Paulo: McGraw-Hill Ltda. 1987. $381 \mathrm{p}$.

COUTINHO, Marcelo James Vasconcelos. Administração pública voltada para o cidadão: quadro teórico-conceitual. Revista do Serviço Público. ano 51, n. 3, jul-set 2000

DAVID, René. Os Grandes Sistemas do Direito Contemporâneo, trad. Hermínio A. Carvalho. 2. ed. São Paulo: Martins Fontes. 1993. 556p.

DI PIETRO, María Sylvia Zanella. Direito Administrativo. 10. ed. São Paulo: Atlas. $577 \mathrm{p}$.

DINIZ, Eli. Globalização, Ajuste e Reforma do Estado. Revista Brasileira de Informaçẫo em Ciências Sociais-RBIB. n. 45, $1^{\circ}$ semestre de 1998. 
BOSCHI, Renato; LESSA, Renato. Modemização e Consolidação Democrática no Brasil: dilemas da nova república. São Paulo: Vértice e Revista dos Tribunais. 1989.190p.

DURANT, Will. A História da Filosofia, tradução de Luiz Carlos do Nascimento Silva. Rio de Janeiro: Nova Cultural. 1996.480p.

FIORI, José Luís. O Vôo da Coruja: uma leitura não liberal da crise do estado desenvolvimentista. Ruo de Janeiro; UERJ. 1995. 133p.

FIORI, José Luís TAVARES, Maria da Conceiçấo (Des)ajuste Globale Modernizaçāo Conservadora. Rio de Janeiro: Paz e Terra. 1993. 193p.

FOWLER Jr, Floyd J. Survey Research Methods. Boston; SACE Publications. $1987.159 \mathrm{p}$.

FREITAG, Bárbara. A Teoria Crítica Ontem e Hoje. 5. ed São Paulo: Brasiliense. 1994. $184 \mathrm{p}$.

FURTADO, Celsc. O Mito do Desenvolvimento Econômico. Rio de Janeiro: Paz e Terra. 1996. 89p. (Coleçä́o Cultura)

GIRGLIOLI, Pier Paolo. Burocracia. In: BOBBIO, Norberto; MATTEUCCl, Nicola; PASQUINO, Gianfranco et al Dicionário de Política, trad. Carmen C. Varriale et al. 10. ed. Brasilia: Universidade de Brasilia. v.2. 1997. p. 124-130.

GRUPPI, Luciano. Tudo Começou com Maquiavel - as concepçōes de Estado em Marx, Engels, Lênin e Gramsci. Porto Alegre: L8PM. 1980. 92p.

HABERMAS, Jürgen. Historia y Crítica de la Opiniôn Pública la tranisformación estructural de la vida pública, trad. Antonio Doménechi, Barcelona: G.Gili S.A. de C.V. $1994352 \mathrm{p}$

Dircito e Democracia, entre facticidade e validade, trad. Flávio Beno Siebeneichler. Rio de Janeiro: Tempo Universitário. v.2. 1997. 352p.

HEILBRONER, Robert. A História do Pensamento Fconomico, trad Therezinha M. Deutsch e Sylvio Deutsch. São Paulo: Nova Cultural 1996.319p.

IANNI, Octavio (org) Marx. São Paulo Ática. 1987.214p. (coleçâo grandes cientistas sociais)

JAY, Martin. La Imaginación Dialéctica - una historia de la Escuela de Frankfurt, Madrid: Taurus. $1986.509 \mathrm{p}$.

KUCINSK, Bemardo; BRANFORD, Sue A Ditadura da Dívida - causas e conseqũências da dívida latino-americana. São Paulo: Brasiliense. 1987.223p.

KURZ, Robert. O Colapso da Modemização - da derrocada do socialismo de casema à crise da economia mundial, trad Karen Elsabe Barbosa. 4 ed. Rio de Janeiro: Paz e Terra. 1996. 244p. 
LUHMANN, Niklas. Por Que uma 'Teoria dos Sistemas'? In: STEIN, Emildo e BONI, Luís A. de (org.). Dialética e Liberdade, festschrift em homenagem a Carlos Roberto Cime Lima. Porto Alegre: UFRGS. 1993.

MARCUSE, Herbert. Cultura e Sociedade, trad. Wolfgang Leo Maar et al. Rio de Janeiro: Paz e Terra. v.2. 1998. 175p.

MEIRELLES, Hely Lopes. Direito Administrativo Brasileiro. 25. ed. São Paulo: Malheiros, 2000.765p.

MERQUIOR, José Guilherme. Arte e Sociedade em Marcuse, Adorno e Benjamin - ensaio crítico sobre a escola neohegeliana de Frankfurt. Rio de Janeiro: Tempo Brasileiro. 1969. 311p.

MICHELS, Robert. Os Partidos Políiticos, trad. Hamilton Trevisan. Săo Paulo: Senzala. (s.d.). 254p.

OFFE, Claus. Critérios de Racionalidade e Problemas Funcionais da Açâo Politico-Administrativa. 1974, in: OFFE, Claus, Problemas Estruturais do Estado Capitalista, traduçāo de Bárbara Freitag. Rio de Janeiro: Tempo Brasileiro. 1984. 386p.

OFFE, Claus; LENHARDT, Gero. Teoria do Estado e Política Social - tentativas de explicaçāo político-sociológica para as funçōes e os processos inovadores da política social. 1977. In: OFFE, Claus, Froblemas Estruturais do Estado Capitalista, tradução de Bárbara Freitag, Rio de Janeiro: Tempo Brasileiro, $1984,386 \mathrm{p}$.

'A Ingovernabilidade': Sobre o Renascimento das Teorias Conservadoras da Crise. 1979. In: OFFE, Claus, Problemas Estruturais do Estado Capitalista, tradução de Bárbara Freitag. Rio de Janeiro: Tempo Brasileiro. 1984. 386p.

. A Democracia Partidána Competitiva e o 'Welfare State Keynesiano: fatores de estabilidade e desorganização 1983. In: OFFE, Claus. Problemas Estruturais do Estado Capitalista, traduçāo de Bárbara Freitag. Rio de Janeiro: Tempo Brasileiro. 1984. 386p.

Problemas Estruturais do Estado Capitalista, tradução de Bárbara Freitag. Rio de Janeiro: Tempo Brasileiro. 1984. 386p.

PASQUINO. Gianfranco. Govemabilidade In: BOBBIO Norberto; MATTEUCCI, Nicola e PASQUINO, Ganfranco et al. Dicionário de Política, trad. Carmen C. Varriale et al., 10 ed. Brasflia: Universidade de Brasilia. v.2. 1997. p. 547-553.

PEREIRA, Luiz Carlos Bresser. Da Administraçāo Pública Burocrática à Gerencial. Revista do Serviço Público. ENAP, Brasllia, ano 47. v. 120. n. I. jan -abr 1996. 
A Reforma do Estado dos anos 90: Lógica e mecanismos de controle, Brasilia: Ministério da Administração Federal e Reforma do Estado. 1997. 58p. (Cademos MARE da reforma do estado; c. 1 )

REGONINI, Gloria. Estado do Bem-Estar. In: BOBBIO, Norberto; MATTEUCCI, Nicola; $\mathrm{PASQUINO}$, Gianfranco et al. Dicionário de Política, trad. Carmen C. Varriale et al. 10 ed. Brasilia: Universidade de Brasilia. v.2. 1997. p. 416-419.

RIO GRANDE DO SUL, Projeto Reforma do Estado do Rio Grande do Sul carta consulta COFIEX, Porto Alegre: Secretaria da Coordenação e Planejamento, Secretaria da Fazenda, Sistema Financeiro Estadual. 1995. $71 \mathrm{p}$.

CONTRATO DE EMPRÉSTIMO (Programa de Reforma do Estado do Rio Grande do Sul) entre Banco Internacional para Reconstruçāo e Desenvolvimento e Estado do Rio Grande do Sul, celebrado em 10 de junho de 1997, trad. Kurt Albert Goldberg; segundo Richard M. Labrie. Tabeliăo Público. $17 \mathrm{fls}$.

SANCHES Osvaldo Maldonado. Dicionário de Orçamento; Planejamento e Áreas Afins. Brasflia: Prisma. 1997.

SCHIRM, Stefan A. Mercados Globais e Margem de Ação do Estado, papers n. ${ }^{\circ}$ 36. São Paulo: Fund. Konrad Adenauer. 1999. 58p.

TIRONI, Luís Fernando; SILVA, Luiz Carlos Eichernberg; VIANNA, Solon Magalhāes et al. Critérios para Geração de Indicadores de Qualidade e Produtividade no Serviço Público. Texio para Discussäo n. ${ }^{\circ} 238$. Brassilia: IPEA. 1991.

TRAGTENBERG, Mauricio. Burocracia e Ideologia. 2 ed. Sảo Paulo: Atlas. 1992. 219p.

WEBER, Max. A Ética Protestante e o Espínito do Capitalismo. Sảo Faulo: UNB - Pioneira. 1981. (Coleçäo Weberiana)

Economia y Sociedad - Esbozo de sociología comprensiva. 11. reinpresión, Cidad del Mexico: Fondo de Cultura Económica. 1997. 1237p. 